\title{
Carbon Dioxide Fixation as the Initial Step in the Metabolism of Acetone by Thiosphaera pantotropha
}

\author{
By E. M. BONNET-SMITS, ${ }^{1,2}$ L. A. ROBERTSON, ${ }^{1}$ J. P. VAN DIJKEN, \\ E. SENIOR ${ }^{2}$ AND J. G. KUENEN ${ }^{1 *}$ \\ ${ }^{1}$ Department of Microbiology and Enzymology, Delft University, Julianalaan 67A, \\ 2628 BC Delft, The Netherlands \\ ${ }^{2}$ Department of Bioscience and Biotechnology, Applied Microbiology Division, University of \\ Strathclyde, 204 George Street, Glasgow G1 1XW, UK
}

(Received 9 February 1988; revised 6 April 1988)

\begin{abstract}
Evidence is presented for a new pathway of acetone metabolism in Thiosphaera pantotropha. The initial step involves a carboxylation, probably resulting in the formation of acetoacetate. Cells grown on acetone and propan-2-ol fixed large quantities of ${ }^{14} \mathrm{CO}_{2}$, in contrast to cells grown on acetate and acetoacetate. Growth on acetone and propan-2-ol, but not on other substrates, was dependent on the exogenous supply of $\mathrm{CO}_{2}$. NMR studies on the labelling pattern of the intracellular poly- $\beta$-hydroxybutyrate (PHB) confirmed that $\mathrm{C}_{2}$ units are produced from acetone after initial carboxylation. The metabolism of acetone and propan-2-ol was associated with drastic changes in the ultrastructure of the organisms. During growth on these substrates, proteinaceous, crystalline inclusions were observed. These were absent in acetate-grown cells. The nature of these crystalline inclusions remains to be elucidated.
\end{abstract}

\section{INTRODUCTION}

A number of different pathways for the aerobic microbial metabolism of acetone have been studied by several groups of investigators. Levine \& Krampitz (1952) proposed that an unidentified soil isolate oxidized acetone to acetaldehyde and a $C_{1}$ fragment. Rudney (1954), studying acetone metabolism in the rat, suggested the hydration of the enol form of acetone to 1,2-propanediol; this was then metabolized to acetol. Evidence for this pathway in microorganisms was given by the work of Lukins \& Foster (1963), who showed that acetol is an intermediate in acetone degradation by Mycobacterium smegmatis. Taylor et al. (1980) also suggested that the metabolism by a soil bacterium of acetone proceeds via acetol. However, an enzyme capable of converting acetone to acetol has not, so far, been described in the literature.

Vestal \& Perry (1969) showed that isocitrate lyase was induced in Mycobacterium vaccae JOB 5 during growth on propane. This was thought to indicate that propane degradation proceeds via propan-2-ol and acetone to acetol, followed by a cleavage to $C_{1}$ and $C_{2}$ fragments. Both Coleman \& Perry (1984) and Stephens \& Dalton (1986) proposed a subterminal oxidation in propane degradation with acetone as an intermediate. From all this work it became clear that at least two pathways of acetone metabolism may exist (Fig. 1). The main factor in one pathway is that an oxygenase is assumed to catalyse the first step of acetone oxidation.

Robertson \& Kuenen (1983) described a new species, Thiosphaera pantotropha, which was capable of anaerobic growth on acetone, with nitrate as electron acceptor. As an oxygenase cannot be involved in this case, another pathway must be present. In this paper, a novel route for acetone metabolism in $T$. pantotropha is described.

Abbreviation: PHB, poly- $\beta$-hydroxybutyrate. 


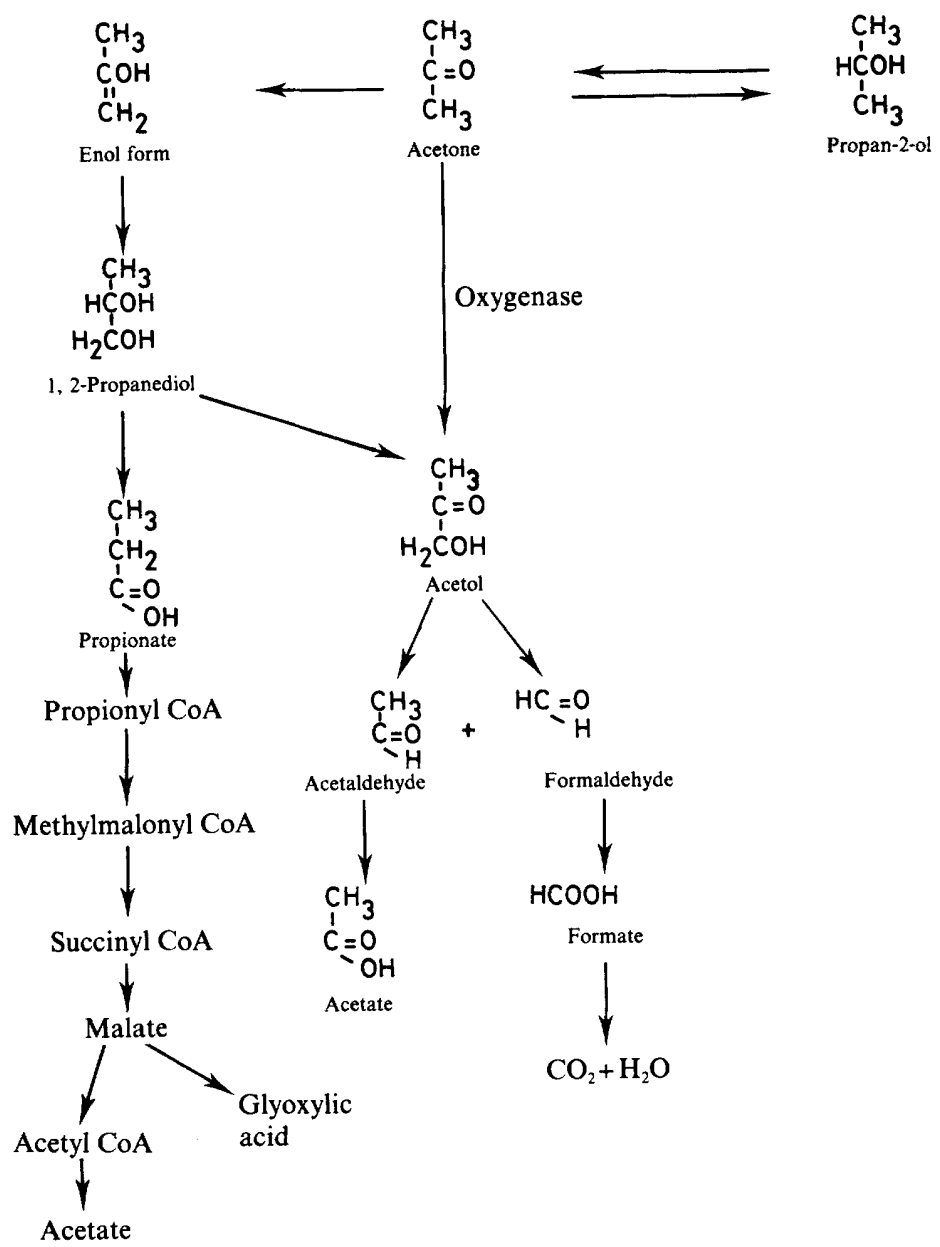

Fig. 1. Combined pathways of acetone metabolism in different bacteria as proposed by Vestal \& Perry (1969) and Taylor et al. (1980). The conversion of 1,2-propanediol into propionate by a dehydrogenation is followed by the propionate metabolism pathway described by Vestal \& Perry, (1969).

\section{METHODS}

Media and culture conditions. The organism used was Thiosphaera pantotropha (LMD 82.5, Delft culture collection). It was maintained on agar slopes consisting of mineral salts medium solidified with $2 \%$ Difco Bacto agar and with $20 \mathrm{~mm}$-sodium acetate as carbon and energy source. The incubation temperature was $37^{\circ} \mathrm{C}$. The organism was grown in a mineral medium described by Robertson \& Kuenen (1983) at $\mathrm{pH} 7 \cdot 3$. Acetone and propan-2-ol were not autoclaved, but diluted in sterile water. Non-volatile substrates in the liquid media were sterilized separately and added to a final concentration of $10 \mathrm{mM}$. Arthrobacter A1 was kindly provided by P. W. Trudgill, Department of Biochemistry, University College of Wales, Aberystwyth, UK. It was grown as described by Taylor et al. (1980).

Growth in batch culture. T. pantotropha was grown in batch culture in $100 \mathrm{ml}$ flasks with $25 \mathrm{ml}$ mineral medium. The medium was inoculated from a slope and incubated on a rotary shaker at 200 r.p.m. at $37^{\circ} \mathrm{C}$. After $48-72 \mathrm{~h}$ of growth the organism was subcultured. From this subculture $5 \mathrm{ml}$ was transferred into $250 \mathrm{ml}$ medium in a 1 litre flask. The end of exponential growth was reached after $24 \mathrm{~h}$ of incubation. The flask was sealed to prevent evaporation of acetone or propan-2-ol from the medium.

Respiration experiments. Cell suspensions were harvested by centrifugation at $10000 \mathrm{~g}$ for $6 \mathrm{~min}$ at $4^{\circ} \mathrm{C}$, washed with $0.1 \mathrm{M}$-phosphate buffer $\mathrm{pH} 7.0$ and resuspended in the same buffer. Respiration rates of whole cells were determined with a Clark-type oxygen electrode (Yellow Springs Instrument $\mathrm{Co}$.). Endogenous oxygen uptake was measured in washed cell suspensions $(3 \mathrm{ml})$ at $30^{\circ} \mathrm{C}$ for $5 \mathrm{~min}$. After addition of substrate to a final concentration of $3.3 \mathrm{mM}$ the oxygen uptake was followed for at least $5 \mathrm{~min}$. 
Preparation of cell-free extracts and enzyme assays. Approximately $0.5-1.0 \mathrm{~g}$ wet weight of cells were suspended in $2.0 \mathrm{ml} 0.1 \mathrm{M}-\mathrm{KH}_{2} \mathrm{PO}_{4} / \mathrm{K}_{2} \mathrm{HPO}_{4}$ buffer $\mathrm{pH} 7 \cdot 0$. These cells were disrupted by sonication at $0{ }^{\circ} \mathrm{C}$ with an MSE $150 \mathrm{~W}$ sonicator for $4 \times 30 \mathrm{~s}$. Whole cells and debris were removed by centrifugation for $2 \mathrm{~min}$ at $10000 \mathrm{~g}$. Enzyme assays were done at $30^{\circ} \mathrm{C}$ with freshly prepared extracts in a Hitachi model 100-60 spectrophotometer. In all cases the observed rate of absorption decrease was directly proportional to the cell-free extract concentration. Propan-2-ol dehydrogenase (EC 1.1.1.80), acetol dehydrogenase and 1,2-propanediol dehydrogenase (EC 1.1.1.55) were assayed as described by Taylor et al. (1980). Isocitrate lyase (EC 4.1.3.1) and isocitrate dehydrogenase (EC 1.1 1. 1.42) were determined according to Reeves $e$ t al. (1971). Acetoacetate decarboxylase (EC 4.1.1.4) was assayed spectrophotometrically, following the decrease in absorbance at $270 \mathrm{~nm}$, as described by Fridovich (1972).

Accumulation and NMR analysis of poly- $\beta$-hydroxybutyrate $(P H B)$. The precultures were made in mineral medium, as already described. However, in order to stimulate PHB accumulation, the concentration of the nitrogen source in the final culture was reduced to $0.1 \mathrm{~g} \mathrm{NH}_{4} \mathrm{Cl} \mathrm{l}^{-1}$. Acetone was added to a final concentration of $40 \mathrm{~mm}$. An excess of ${ }^{13} \mathrm{CO}_{2}$ was provided by the addition of $\mathrm{NaH}^{13} \mathrm{CO}_{3}$ to a final concentration of $50 \mathrm{~mm}$.

After $25 \mathrm{~h}$ of incubation at $37^{\circ} \mathrm{C}$ on a rotary shaker, cells were harvested and washed with $0.1 \mathrm{M}$-phosphate buffer $\mathrm{pH} 7.0$. The cells were washed with acetone and dried under vacuum at room temperature. PHB was extracted with chloroform in a Soxhlet apparatus as described by Doi et al. (1986). The NMR analyses of PHB, dissolved in chloroform, were done on a Nicolet NT-200 WB spectrometer operating at $50 \cdot 3 \mathrm{MHz}$ for a ${ }^{13} \mathrm{C}$ spectrum and $200 \mathrm{MHz}$ for a ${ }^{1} \mathrm{H}$ spectrum at $27^{\circ} \mathrm{C}$.

Analytical procedures. The protein content of whole cells and cell-free extracts were determined by the microbiuret method (Goa, 1953).

High-performance liquid chromatography (HPLC) was done in a chromatographic system consisting of a Waters model $6000 \mathrm{~A}$ pump, a Waters U6K injector, and a Hewlett-Packard 1040 A photodioxide array detector. Proteins were analysed on a Superose 6 size exclusion column $(4 \times 250 \mathrm{~mm}$, Pharmacia) with 0.1 M-potassium phosphate buffer, $\mathrm{pH} 6.5$, as the eluant at a flow rate of $0.5 \mathrm{ml} \mathrm{min}^{-1}$. Either whole spectra or the absorbances at six wavelengths were recorded with a frequency of 16 spectra or points $\min ^{-1}$ (Frank et al., 1987).

Preparation of cell suspensions for ${ }^{14} \mathrm{CO}_{2}$ fixation experiments. After $24 \mathrm{~h}$ growth in the mineral salts medium with $10 \mathrm{~mm}$-acetone, the culture was harvested and washed in acetone-free medium. The cells were then centrifuged at $4{ }^{\circ} \mathrm{C}$ at $10000 \mathrm{~g}$ for $6 \mathrm{~min}$. The pellet was resuspended in $15 \mathrm{ml}$ of the medium without acetone.

${ }^{14} \mathrm{CO}_{2}$ fixation experiments were done at $30^{\circ} \mathrm{C}$ in a $2 \mathrm{ml}$ vial under magnetic stirring. The reaction mixture contained $540 \mu \mathrm{l}$ cell suspension and different concentrations of acetone to a final volume of $600 \mu \mathrm{l}$. After $2 \mathrm{~min}$ incubation, $120 \mu \mathrm{l} 50 \mathrm{~mm}-\mathrm{NaH}^{14} \mathrm{CO}_{3}$ with an activity of $23.75 \mu \mathrm{Ci} \mathrm{ml}^{-1}\left(87.875 \mathrm{~Bq} \mathrm{ml}^{-1}\right)$ was added. Samples $(100 \mu \mathrm{l})$ of the reaction mixture were filtered through $25 \mathrm{~mm}$ Gelman membrane filters (pore size $0.45 \mu \mathrm{m}$ ) at fixed time intervals, and washed with $\mathrm{HPO}_{4}^{2-} / \mathrm{NaHCO}_{3}$ buffer (each $50 \mathrm{~mm}, \mathrm{pH} 8.0$ ). The radioactivity of the filters was measured in a Beckman LS 3801 scintillation counter after the addition of $10 \mathrm{ml}$ Scintillator 299 (Packard). To determine the radioactivity of the $50 \mathrm{mM}-\mathrm{NaH}^{14} \mathrm{CO}_{3}$ solution, $10 \mu \mathrm{l}$ was added to $1 \mathrm{ml}$ Carbosorb (Packard), and counted as described above.

Chemicals. $\mathrm{NaH}^{13} \mathrm{CO}_{3}$ and $\mathrm{NaH}^{14} \mathrm{CO}_{3}$ were obtained from Amersham. ${ }^{13} \mathrm{C}$ in $\mathrm{NaH}^{13} \mathrm{CO}_{3}$ was available at an enrichment of $90 \%{ }^{13} \mathrm{C}$. The $\mathrm{NaH}^{14} \mathrm{CO}_{3}$ had a specific activity of $56 \mathrm{mCi} \mathrm{mmol}^{-1}$. Acetone and propan-2-ol were from Baker Chemicals and bovine serum albumin was from Merck. All other chemicals used were also of analytical grade.

\section{RESULTS}

\section{Oxidation of acetone by whole cells}

$T$. pantotropha could be grown both aerobically and anaerobically, with nitrate, on acetone and propan-2-ol. All studies were done with aerobic cultures. Respiration studies with washed cell suspensions showed that cells grown on a variety of substrates could oxidize acetate (Table 1). Both acetone- and propan-2-ol-grown cells oxidized acetone and propan-2-ol, whereas acetate- and glucose-grown cells did not. This suggested that the metabolism of acetone and propan-2-ol proceeds via the same or a closely related pathway in this organism. Cells grown with 1,2-propanediol showed only a low oxidation rate for propan-2-ol, and could not oxidize acetone.

\section{Activities of enzymes in cell-free extracts}

Propan-2-ol dehydrogenase was not detected in either acetone- or propan-2-ol-grown cells. Control experiments with Arthrobacter A1 confirmed the reported levels of this enzyme $\left[0 \cdot 210 \mu \mathrm{mol} \mathrm{min}^{-1} \text { (mg protein) }\right)^{-1}$, Taylor et al., 1980]. Propan-2-ol dehydrogenase in 
Table 1. Maximum rates of substrate-dependent oxygen uptake by washed cell suspensions of T. pantotropha

Cells were grown aerobically on the substrates indicated. Final assay substrate concentrations were $3.3 \mathrm{mM}$. Values are expressed in $\mathrm{nmol} \mathrm{O}_{2}$ consumed $\mathrm{min}^{-1}$ (mg protein $)^{-1}$.

\section{Assay \\ substrate}

Acetone

Propan-2-ol

1,2-Propanediol

Propanol

Acetol

Sodium acetate

122
128
$<5$
120
64
279

Rate of oxygen uptake

Growth substrate:

Propan-2-ol
149
124
$<5$
131
ND
260

1,2-Propanediol
$<5$
22
45
ND
346
52

ND, Not determined.

$\begin{array}{cc}\begin{array}{c}\text { Sodium } \\ \text { acetate }\end{array} & \text { Glucose } \\ & \\ <5 & <5 \\ <5 & <5 \\ <5 & <5 \\ 47 & 28 \\ 125 & 43 \\ 530 & 74\end{array}$

T. pantotropha was also not detected in assays using phosphate buffers over a $\mathrm{pH}$ range of 7-10. The substitution of NADH by NADPH or FADH also yielded negative results. Furthermore, the use of an artificial electron donor such as PES (phenazine ethosulphate) in combination with DCPIP (2,6-dichlorophenolindophenol) failed to detect propan-2-ol dehydrogenase activity. Acetol dehydrogenase was also not detected.

All extracts prepared from cells grown on acetone, propan-2-ol or acetate showed a high NADP-dependent isocitrate dehydrogenase activity $\left[0.280-1.500 \mu \mathrm{mol} \mathrm{min}^{-1}(\mathrm{mg} \text { protein })^{-1}\right]$.

Isocitrate lyase was detected in Arthrobacter A1, $\left[0 \cdot 020 \mu \mathrm{mol} \mathrm{min}^{-1} \text { (mg protein) }\right)^{-1}$, Taylor et al., 1980], but not in T. pantotropha. As isocitrate lyase was also not detected in acetate-grown cells it seems likely that $T$. pantotropha, like the physiologically related Thiobacillus versutus (Claassen et al., 1987), does not metabolize $\mathrm{C}_{2}$ compounds via the glyoxylate cycle under normal aerobic growth conditions. All these results indicated that the acetone-metabolizing pathway operating in $T$. pantotropha is different from those reported in the literature.

\section{Dependence of acetone metabolism on exogenous $\mathrm{CO}_{2}$}

A novel metabolic route for (an)aerobic acetone metabolism might involve a carboxylation of the methyl group. This would be analogous to the carboxylation of pyruvate to oxaloacetate found in anaerobes such as the propionic acid bacteria Propionibacterium acidipropionici and Veillonella alcalescens (Schlegel, 1985). Carboxylation of acetone would produce acetoacetate, which is a key intermediate in most aerobic and anaerobic bacteria.

$$
\mathrm{CH}_{3}-\mathrm{CO}-\mathrm{CH}_{3}+\mathrm{CO}_{2} \rightarrow \mathrm{CH}_{3}-\mathrm{CO}-\mathrm{CH}_{2}-\mathrm{COOH}
$$

Growth studies with $T$. pantotropha in shake flasks with $\mathrm{KOH}$ in a centre well (to absorb $\mathrm{CO}_{2}$ ) revealed that the organism could only use acetone as a growth substrate in the presence of $\mathrm{CO}_{2}$. This indicated that $\mathrm{CO}_{2}$ is a necessary growth factor. Growth on propan-2-ol was also dependent on the presence of $\mathrm{CO}_{2}$. In contrast, growth on several other substrates including acetate, acetol, propanol, 1,2-propanediol and acetoacetate was not affected by the removal of $\mathrm{CO}_{2}$. It can therefore be concluded that the catabolism of acetone and propan-2-ol by $T$. pantotropha proceeds via a metabolic route that differs from that used for other $C_{3}$ compounds, including 1,2propanediol. As 1,2-propanediol is a presumptive intermediate in most of the known pathways of acetone metabolism (Fig. 1), this also indicates that $T$. pantotropha is using a novel route.

$$
\text { In vivo fixation of }{ }^{14} \mathrm{CO}_{2}
$$

The lack of growth in the absence of $\mathrm{CO}_{2}$ suggested that $\mathrm{CO}_{2}$ uptake was a necessary step in acetone and propan-2-ol breakdown. It was therefore attempted to quantify $\mathrm{CO}_{2}$ fixation via radiorespirometry in acetone-grown cells. It was observed that the amount of ${ }^{14} \mathrm{CO}_{2}$ fixed into biomass was a function of the initial acetone concentration (Fig. 2). Acetate supplied to acetone- 


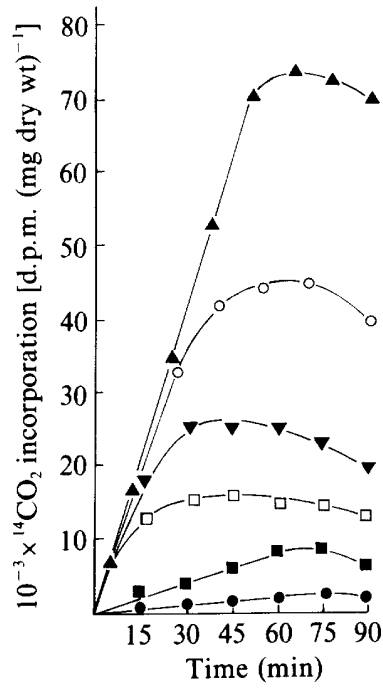

Fig. 2. Incorporation of ${ }^{14} \mathrm{CO}_{2}$ in whole cells of $T$. pantotropha with 4.0 mM-sodium acetate $(\square)$ or varying concentrations of acetone: $0.5 \mathrm{mM}(\square) ; 1.0 \mathrm{mM}(\nabla) ; 2.0 \mathrm{mM}(\bigcirc)$; and $4.0 \mathrm{mM}(\boldsymbol{A})$. $\bigcirc$, No added substrate.

grown cells gave a very low level of $\mathrm{CO}_{2}$ fixation. $\mathrm{CO}_{2}$ fixation with acetone was approximately 10 -fold higher than that in the presence of acetate. When the cells had been pregrown on acetate rather than on acetone, the short-term ${ }^{14} \mathrm{CO}_{2}$ fixation with acetone as a substrate was insignificant (data not shown).

\section{Evidence for ${ }^{13} \mathrm{CO}_{2}$ fixation during synthesis of $\mathrm{PHB}$ from acetone}

Since carboxylation of acetone would result in the formation of acetoacetate, it was anticipated that this intermediate could not only serve to produce acetyl CoA for biosynthesis and energy generation, but also as the precursor of the synthesis of PHB. Under some growth conditions (e.g. under nitrogen limitation), PHB can constitute as much as $50 \%$ of the total biomass in $T$. pantotropha. Incorporation of labelled $\mathrm{CO}_{2}$ into PHB might thus be expected to reflect the labelling of acetone. Therefore, ${ }^{13} \mathrm{CO}_{2}$ incorporation into PHB was studied in a nitrogen-limited culture of $T$. pantotropha grown with excess acetone and $\mathrm{CO}_{2}$. Qualitative analysis of PHB formation in cultures was done with NMR spectroscopy. By using ${ }^{13} \mathrm{CO}_{2}$ in these experiments, the position of the $\mathrm{CO}_{2}$ incorporated in the PHB molecule could be detected. Fig. 3 shows a $200 \mathrm{MHz}{ }^{1} \mathrm{H}-\mathrm{NMR}$ spectrum of unlabelled PHB. In this spectrum four lines are observed, representing the four carbon configurations in the molecule. When PHB which had accumulated in cultures with an excess of acetone and ${ }^{13} \mathrm{CO}_{2}$ was analysed, only the two lines representing the two ${ }^{13} \mathrm{C}$-labelled carbon configurations at 169.074 and 67.600 p.p.m. were observed (Fig. 4). The three lines at 77.0 p.p.m. are (as in Fig. 3) due to the chloroform, which was used as the solvent for the PHB extraction. This NMR spectrum thus reveals that ${ }^{13} \mathrm{CO}_{2}$ was incorporated only in the $\mathrm{C}-1$ and $\mathrm{C}-3$ positions.

\section{Ultrastructure of acetone- and propan-2-ol-grown cells}

Electron micrographs of cells grown on acetone or propan-2-ol revealed the presence of crystalline proteinaceous inclusions. (Fig. 5). These structures were only produced at the end of the exponential growth phase in cells grown on either acetone or propan-2-ol and were absent in acetate-grown cells.

HPLC analysis of extracts (Fig. 6) of cells grown on acetone and propan-2-ol revealed the presence of a protein with an $M_{\mathrm{r}}$ of about 172500 at a retention time of $22.30 \mathrm{~min}$ and another peak with an $M_{\mathrm{r}}$ of about 100500 at a retention time of $24.72 \mathrm{~min}$. These two peaks were absent in extracts from acetate-grown cells. 


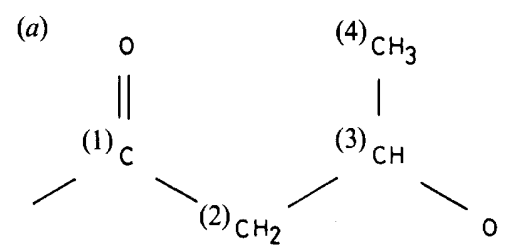

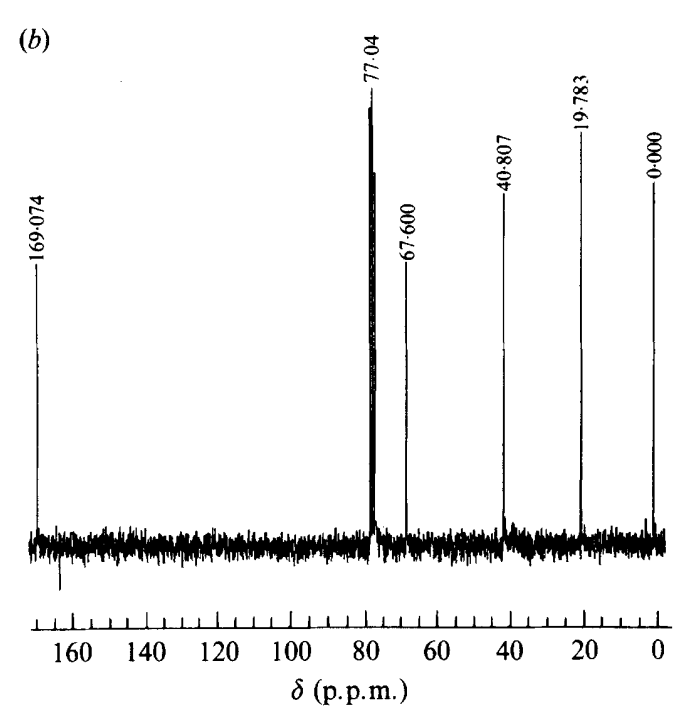

Fig. 3

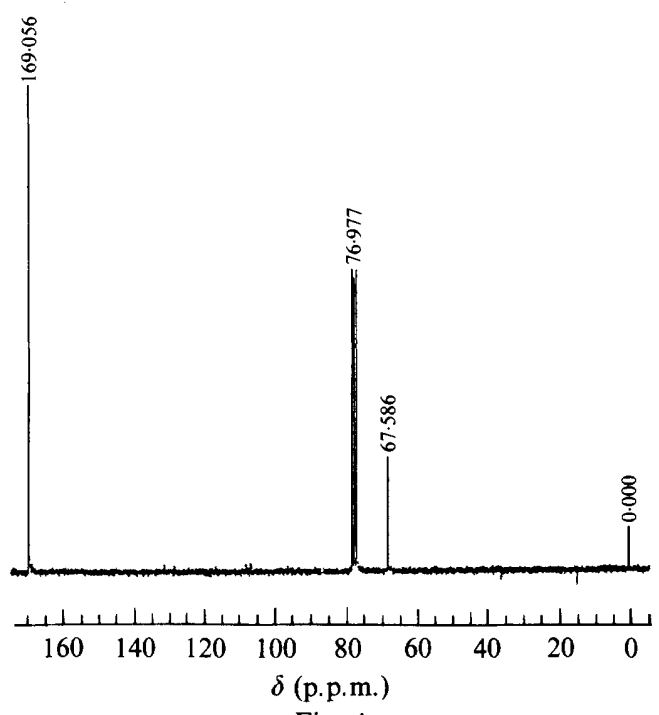

Fig. 4

Fig. 3. (a) Structural formula of the repeating unit of the PHB molecule. (b) ${ }^{1} \mathrm{H}$ NMR spectrum $(200 \mathrm{MHz})$ of unlabelled PHB in chloroform at $27^{\circ} \mathrm{C}$. PHB was extracted from cells of T. pantotropha grown under nitrogen limitation with an excess of acetone and $\mathrm{NaHCO}_{3}$. The numbered carbons in $(a)$ gave rise to the peaks at 169.074 p.p.m. (C-1), 40.807 p.p.m. (C-2), 67.600 p.p.m (C-3) and 19.783 p.p.m. (C-4) shown in (b). The peak at 77.04 p.p.m. is due to the chloroform solvent.

Fig. 4. ${ }^{13} \mathrm{C}$ NMR spectrum (50.3 MHz) of PHB in chloroform at $27^{\circ} \mathrm{C}$. PHB was extracted from cells of $T$. pantotropha grown under nitrogen limitation with an excess of acetone and $\mathrm{NaH}^{13} \mathrm{CO}_{3}$. The peaks at 169.056 and 67.586 p.p.m. correspond, respectively, to C-1 and C-3 in Fig. $3(a)$. The peak at 76.977 is due to the chloroform solvent.

\section{DISCUSSION}

Evidence for ${ }^{13} \mathrm{CO}_{2}$ fixation during synthesis of $\mathrm{PHB}$ from acetone

The labelling pattern of the ${ }^{13} \mathrm{CO}_{2}-\mathrm{NMR}$ spectrum of PHB (Fig. 4) can be explained by assuming that acetoacetate is the first product of acetone metabolism. $\mathrm{CO}_{2}$ is coupled to one of the methyl groups of acetone to form acetoacetate. Acetoacetate can then be metabolized by means of a direct conversion to acetoacetyl-CoA, which may be followed by reduction to $\beta$ hydroxybutyrate. The resulting PHB would then contain a label at the $\mathrm{C}-1$ position. Acetoacetyl$\mathrm{CoA}$ might also be converted to acetyl-CoA for biosynthesis. Particularly during nitrogen limitation, a large pool size of acetyl-CoA would allow re-synthesis of acetoacetyl-CoA, which then would result in PHB with a label at either the $\mathrm{C}-1$ or the $\mathrm{C}-3$ position. Thus the highest amount of label at the $\mathrm{C}-1$ position and the somewhat lower amount of label at the C-3 position would be consistent with acetoacetate (or acetoacetyl CoA) as the first product. A similar pathway has recently been described for anaerobic acetone metabolism by an anaerobic enrichment culture producing methane from acetone (Platen \& Schink, 1987). The evidence indicates that in a coculture of two organisms, acetone is carboxylated to acetoacetate by a eubacterium, which subsequently excretes acetate. The acetate can then be metabolized by a Methanothrix sp. to give methane. 


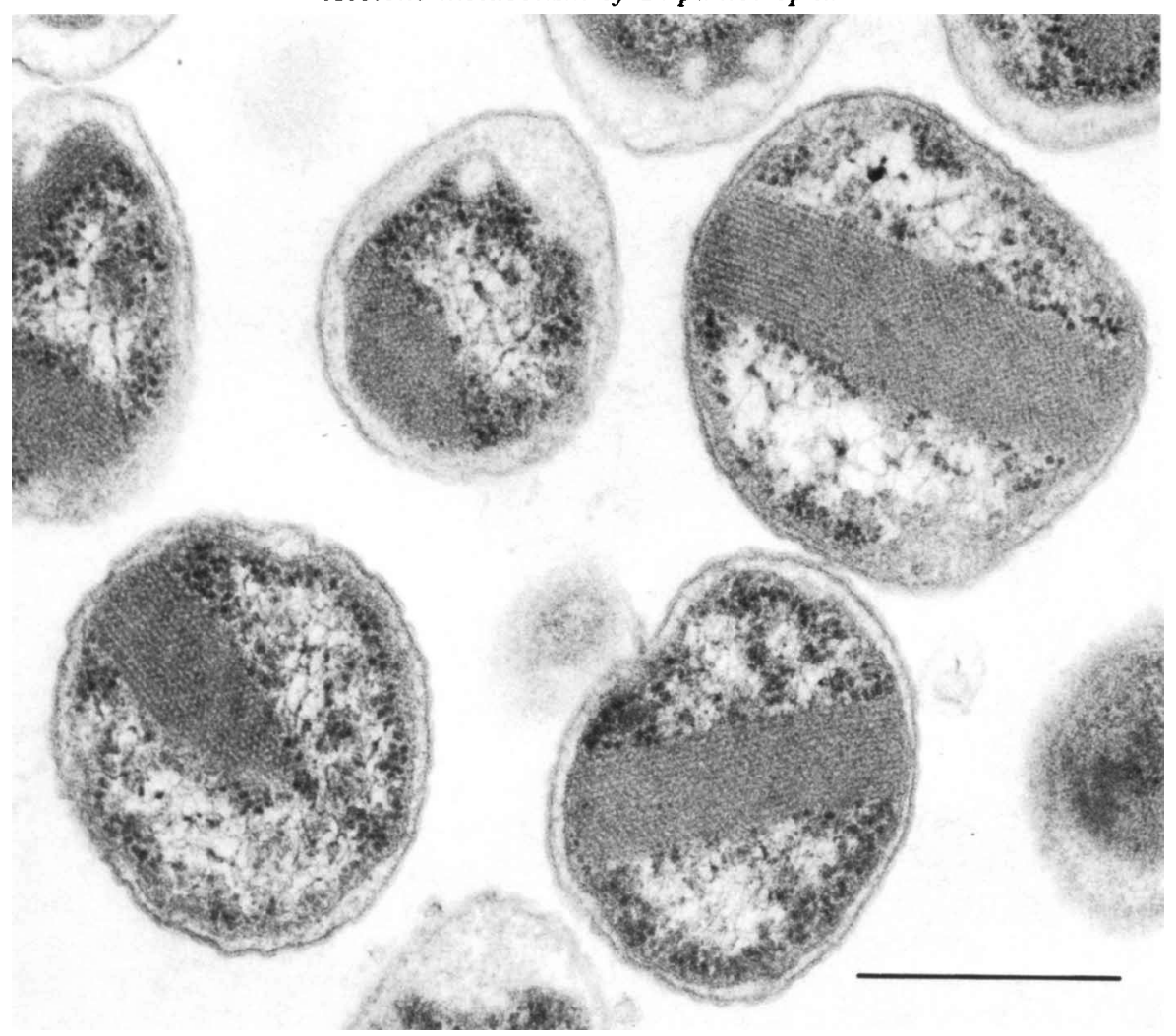

Fig. 5. Electron micrograph of cells of $T$. pantotropha after the end of exponential growth on either acetone or propan-2-ol. Bar, $0.5 \mu \mathrm{m}$.

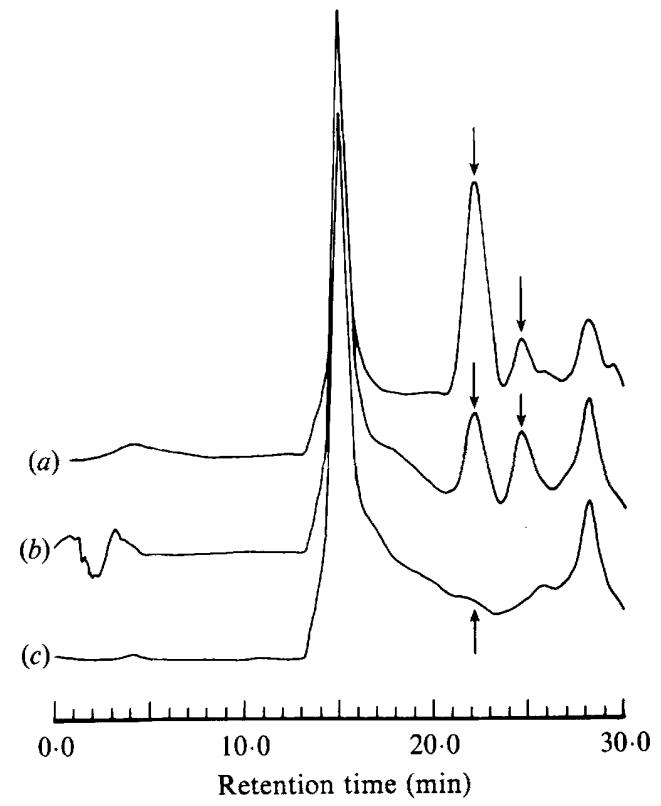

Fig. 6. HPLC of cell-free extracts of cells of $T$. pantotropha grown on propan-2-ol $(a)$, acetone $(b)$ or sodium acetate $(c)$. The arrows point to the peaks at the retention times of 22.3 and $24.7 \mathrm{~min}$, which represent two proteins with $M_{\mathrm{r}}$ values of 172500 and 100500 respectively. 

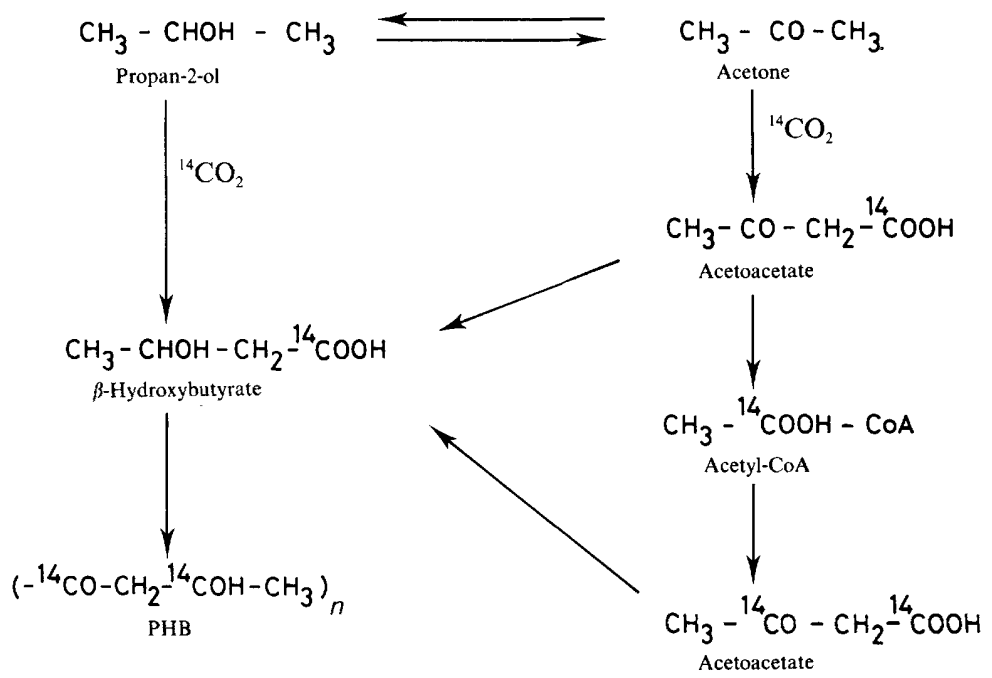

Fig. 7. Proposed pathway for the metabolism of acetone and propan-2-ol by $T$. pantotropha.

\section{Ultrastructure of acetone- and propan-2-ol-grown cells}

The electron micrographs of acetone- or propan-2-ol-grown cells showed regular patterns, probably associated with crystalline proteinaceous material (Fig. 5). The crystalline patterns were absent from acetate-grown cells, and have not previously been observed in $T$. pantotropha grown on a variety of different inorganic and organic compounds (L. A. Robertson \& J. G. Kuenen, unpublished observations). The occurrence in the cell of proteins at such high concentrations that they can easily be seen under the electron microscope has been demonstrated before, for example peroxisomes containing methanol oxidase in the yeast Hansenula polymorpha (van Dijken, 1972) and ribulose 1,5-bisphosphate carboxylase containing particles in the cyanobacterium Anabaena 7122 (Codd \& Stewart, 1976). Interestingly, the crystalline proteins (Fig. 5) appeared only after the end of the exponential growth phase. Whether this is perhaps an indication of derepression of enzymes at the end of exponential growth remains to be elucidated. Given the fact that two major protein bands appeared in extracts of $T$. pantotropha which had been grown on acetone or propan-2-ol, it may be speculated that the crystalline structures contain one, or both, of these proteins. It is also possible that one of these proteins may be the carboxylating enzyme.

\section{Interrelation between acetone and propan-2-ol metabolism}

The results presented above suggest that acetone and propan-2-ol are metabolized by $T$. pantotropha by the same mechanism. However, it is as yet unknown whether propan-2-ol is an intermediate in acetone metabolism, or vice versa. From the point of view of organic chemistry, carboxylation of acetone is more likely than that of propan-2-ol, because the methyl group of the former is more reactive, due to keto-enol tautomerism. If so, it must be assumed that the property of acetone-grown cells to oxidize propan-2-ol is caused by a coordinate induction of a propan-2-ol dehydrogenase, the nature of which is presently unknown. If, however, propan-2-ol turns out to be a functional intermediate during growth on acetone, the possibility of a carboxylation of propan-2-ol rather than of acetone should be considered. The proposed pathway of acetone metabolism in T. pantotropha is presented in Fig. 7.

Although all studies were done with aerobic cells, it may be assumed that this pathway also operates during anaerobic conditions because $T$. pantotropha constantly denitrifies, regardless of the dissolved oxygen concentration (Robertson \& Kuenen, 1984a,b; Kuenen \& Robertson, 1987). At dissolved oxygen concentrations of $80 \%$ of air saturation, as much as $50 \%$ of the heterotrophic respiration has been found to proceed via denitrification rather than oxygen. For 
this reason, it was considered likely that the pathway of acetone and propan-2-ol metabolism would be essentially the same in aerobically and anaerobically grown cells. It is clear that this pathway would circumvent the requirement for an oxygenase as proposed for other organisms, and thus would explain the ability of $T$. pantotropha to grow anaerobically on acetone and propan-2-ol in the absence of oxygen.

We thank Dr G. Fuchs from the University of Ulm, FRG, who suggested the ${ }^{13} \mathrm{C}$-labelling experiments. We are also indebted to Mrs W. M. Batenburg-van der Vegte for doing the electron microscopy, A. Sinnema and J. Peters for the NMR experiments, H. Frank for the HPLC analyses and Hans Bonnet for many stimulating discussions.

\section{REFERENCES}

Claassen, P. A. M., van den Heuvel, M. H. M. J. \& ZEHNDER, A. J. B. (1987). Enzyme profiles of Thiobacillus versutus after aerobic and denitrifying growth; regulation of isocitrate lyase. Archives of Microbiology 147, 30-36.

Codd, G. A. \& Stewart, W. D. P. (1976). Polyhedral bodies and ribulose-1,5-diphosphate carboxylase of the blue-green alga Anabaena cylindrica. 130, 323326.

Coleman, J. P. \& Perry, J. J. (1984). Fate of the $\mathrm{C}_{1}$ product of propane dissimilation in Mycobacterium vaccae. Journal of Bacteriology 160, 1163-1164.

Doi, Y., Kunioka, M., Nakamura, Y. \& Soga, K. (1986). Nuclear magnetic resonance studies on poly$\beta$-hydroxybutyrate and a copolyester of $\beta$-hydroxybutyrate and $\beta$-hydroxyvalerate, isolated from $\mathrm{Alca}$ ligenes entrophus H16. Macromolecules 19, 28602864.

DIJKEN, J. P. VAN (1972). Oxidation of methanol by yeasts. Thesis, University of Groningen, The Netherlands.

Frank, J. JZn, BraAt, A. \& Duine, J. A. (1987). Assessment of protein purity by chromatography and multiwavelength detection. Analytical Biochemistry 162, 65-73.

FRIDOVICH, I. (1972). Acetoacetate decarboxylase. In The Enzymes, 3rd edn, vol. 6, pp. 255-270. Edited by P. D. Boyer. New York, London: Academic Press.

GoA, J. (1953). A microbiuret method for protein determination; determination of total protein in cerebrospinal fluid. Scandinavian Journal of Clinical and Laboratory Investigation 5, 218-222.

KUENEN, J. G. \& ROBERTSON, L. A. (1987). Ecology of nitrification and denitrification. Symposia of the Society for General Microbiology 42, 161-218.

LeVINE, S. \& KRAMPITZ, L. O. (1952). The oxidation of acetone by a soil diphtheroid. Journal of Bacteriology $64,645-650$.
LUKINS, H. B. \& Foster, J. W. (1963). Methylketone metabolism in hydro-carbon utilizing Mycobacteria. Journal of Bacteriology 85, 1074-1087.

Platen, H. \& Schink, B. (1987). Methanogenic degradation of acetone by an enrichment culture. Archives of Microbiology 149, 136-141.

ReEves, H. C., RABIN, R., Wegener, W. S. \& AJL, S. J. (1971). Assay of enzymes of the tricarboxylic acid and glyoxylate cycles. Methods of Microbiology 6A, 452-455.

Robertson, L. A. \& Kuenen, J. G. (1983). Thiosphaera pantotropha gen. nov. sp. nov., a facultatively anaerobic, facultatively autotrophic sulphur bacterium. Journal of General Microbiology 129, 28472855.

Robertson, L. A. \& Kuenen, J. G. (1984a). Aerobic denitrification: a controversy revived. Archives of Microbiology 139, 351-354.

Robertson, L. A. \& Kuenen, J. G. (1984b). Aerobic denitrification-old wine in new bottles? Antonie van Leeuwenhoek 50, 525-544.

RudNeY, H. (1954). Propanediol phosphate as a possible intermediate in the metabolism of acetone. Journal of Biological Chemistry 210, 361-371.

SCHLEGEL, H. G. (1985). Allgemeine Mikrobiologie, 6th edn, pp. 278-281. Stuttgart: Thieme.

Stephens, G. M. \& Dalton, H. (1986). The role of the terminal and subterminal oxidation pathways in propane metabolism by bacteria. Journal of General Microbiology 132, 2453-2462.

Taylor, D. G., Trudgill, P. W., Cripps, R. E. \& HARRIS, P. R. (1980). The microbiol metabolism of acetone. Journal of General Microbiology 118, 159 170 .

Vestal, J. R. \& Perry, J. J. (1969). Divergent metabolic pathways for propane and propionate utilization by a soil isolate. Journal of Bacteriology 99 , 216-221. 